\title{
O MITO DE BORRALHEIRA (1)
}

\begin{abstract}
"Alors ils faisaient vraiment partie de la communion du grand monde, comme les catholiques de nom qui ne s'approchent de la sainte tible qu'une fois l'an".

Proust: Sodome et Gomorihe II, vol. I.
\end{abstract}

Se a moda existe como presença constante na sociedade do século XIX, imiscuindo-se na vida de todo o dia, atxiliando a distribuição dos indivíduos nos grupos e nas camadas sociais, afetando sem cessar a aparência física do ser pelas deformaçes, e a mentalidade através da psicologia especial a que dá origen (a vestimenta confundindo-se com a própria vida em sociedade), porém na vida de exceção, na festa, que ela mais claramente se manifesta e os seus traços se revelam de maneira mais nítida. - "Nada exprime tão bem o estado dos costumes", diz Gaston Richard, "como o papel que a festa representa na vida dos homens e a maneira pela qual eles a celebram" (2). Nada esclarece melhor o sntido profundo da moda que a função que ela desempenha neste nomento agudo da vida dos indivíduos e dos grupos, quando ao si reforçarem os impulsos antagônicos de sociabilidade e de hostilicade (3) acentuam-se também todos os elementos que a caracteriam.

A festa, dissemos, é a vida de exceção. Ela é principalmente aquele "ponto de transição entre a vida real e o nundo da arte" (4). E se houve épocas em que a passagem foi tênuc difícil de per-

(1) Este é o Capltulo V, e último, de uma tese de doutonmento em Sociologia sobre A Moda no século XIX, apresentada en 1950 na antiga Faculdade de Filosofia, Ciências e Let"as da USP, ob orientação do Professo: Roger Bastide. Este trabalho foi editado souco mais tarde, sob forma de separata, pelo Museu Paulista, e desdeentão permaneceu inédito.

Esse texto é republicado agora sem alterações. (Noa da Revista Discurso).

(2) L'évolution des moeurs, pg. 186.

(3) Op. cit., pg. 183: "As relações entre os grupos derivom tanto da hostilidade como da sociabilidade e dão mais facilmente lugar à vingança do sangue que à hospitalidade."

(4) A expressão é de Burckhardt: The Renaissance in Itcly, pg. 246. 
ceber, - tanto a beleza se insinua nas ações humanas, a própria existência sendo concebida como um jogo de perfeição artística outras houve em que foi profunda e representou a ruptura nas obrigações do trabalho e nas exigências triviais da vida quotidiana. No primeiro caso teríamos o Renascimento, cujo esplendor - na vestimenta, na preocupação da polidez, no ideal de conforto, - nos revela uma civilização voltada para o exterior, perseguindo um ideal estético; no segundo, o século XIX, instalando no poder uma burguesia que se encasuia na vida doméstica e toma a sério toda a existência (5).

Agora, estames no apogeu da vida de família. E basta um olhar de relance sobre os desenhos de Ingres - o pintor mais característico da nova ordem - ou para as fotografias de Octavius Hill, de Nadar ou Fox-Tabot, para termos uma idéia da contenção que detém os gestos, bane a alegria e impõe a gravidade. O braço feminino não resvala mais, lânguido, sobre a roupa do homem: pousa recatado no braço do marido, respeitando uma ordem que não permite transbordamentos. Da fisionomia, do jeito de sentar-se com as mãos imperiosas espalmadas sobre os joelhos, de todo o erecto porte masculino ressala a dignidade; a seu lado, esposa e filhos, serenas e virtuosas, compõem a atmosfera recatada do lar. Pois a moral é rígida como os etratados e separa com nitidez os sexos, repudiando intimidades excessivas, impondo regras estritas de decência, na linguagem, nas atiudes, nas ações. O corpo, principalmente o da moça solteira, é cercadó de tabus. E se acaso, nas relações quotidianas, apresenti-se a oportunidade de contacto com um admirador potencial, como por exemplo o professor de aritmética (6), devese, por delicadesa de sentimentos, evitar os vestidos leves de mus-

(5) Huizinga - Homo Ludens, Fondo de Cultura Economica, México, 1943, pg. 89. Eis todo o trecho em que Huizinga descreve o aspecto anti-lúdico lo século XIX:

"As gnndes correntes do pensamento concorrem quase todas contra o fator údico na vida social. Nem o liberalismo, nem o socialismo the oferecen alimento. A ciência experimental e analítica, a filosofia, o utilitarisno e o reformismo políticos, o manchesterianismo, todas são atividaces profundamente sérias. E quando o entusiasmo romântico se esgda na arte e na literatura, aparecem com o realismo e o naturalismo e, sobretudo, com o impressionismo, formas de expressão das mais aheias à idéia de jogo que já floresceram na cultura. Se alguma vez um século se tomou a si mesmo e a toda a sua existência a sério, este foi o século XIX."

(6) Alicia Percival - The English miss to-day and vesterday, Harrap, Londres, 1939 pg. 137: referência a um trecho de romance de Mrs Ewing. "Six to Sitecn". 
selina, que desvendam os ombros, ou os que, muito justos, acentuam demais as formas. E preciso, ainda, ter cuidado com as palavras. Há algumas especialmente perturbadoras, impregnadas de conteúdo emocional, cuja simples menção pode estabelecer entre os interlocutores um vínculo vulgar de intimidade. Em nenhuma ocasião dever-se-ia pronunciar os termos "suor", "calças", "barriga"; e ocorremos o caso de certa senhora brasileira do Segundo Reinado, bastante severa em suas fobias, em cuja presença não se dizia a palavra "coxa". Mesmo quando nas refeições houvesse frango, as filhas deviam pedir apenas "a perna larga".

A festa (7) era, para uma sociedıde deste tipo, mais que para qualquer outra, a ruptura na rigidez dos costumes (8). Quando a existência se tornava cada vez mais árida, a vida quotidiana contrastava com a aspiração do sonho e as eıergias feneciam na clausura dos grupos sexuais, impondo-se a necessidade de uma evasão periódica, de uma pausa na ordem do mund. A festa arremessava os seres nas remotas regiões da fantasia orde, livres temporariamente das interdições e da vigilância rigorosa, hmens e mulheres se abandonavam ao ritmo de suas tendências. (Q vigor que então se inoculava nos seres permitia-lhes "entfrentar) tempo por um novo ciclo" (9).

Neste período de exceção os grupos eminino e masculino, laboriosamente segregados, enfim se defrontaam. E se não encontramos o relaxamento completo das festas prinitivas, presenciamos manifestações bastante dúbias que a sociedade agora aceita com complacência, semi-cerrando os olhos. A luta anorosa alcança o ponto extremo. Os sexos não se entregam à violênia dos recalques, como entre os trobriandeses, por exemplo, quando n instituição do kimali, as mulheres traduzem de maneira inequívoca seu violento impulso amoroso, excitando o grupo masculino atravésdos ditos ofensivos e dos arranhões sangrentos (10). Mas se os côtumes se abrandaram e a sociedade escolhe meios mais sutis, maisimpregnados de elementos lúdicos ou estéticos, é o mesmo impulsc fundamental que se revela:

(7) O termo festa é tomado, neste capítulo, no sentid de reunião mundana da elite.

(8) Ver, sob este ponto de vista o ensaio de Roser Cállois: "Théorie de la Fête" in La Nouvelle Revue Française, ns 315 e 36 , dezembro de 39 e janeiro de 40 .

(9) Caillois, op. cit., 874.

(10) Cfr. Malinovski - The sexual life of savtges in North Western Melanesia, Eugenics Publishing Company, New York, apyright 1929, pgs( 256 e sgs. 
"Ao momento de se encontrar a mão que dava (de Carolina) e a que recebia, Fabrício sentiu que the apartavam os dedos. Seu primeiro pensamento foi crer que era amado; mas logo se lhe apagou esse raio de vaidade, pois que ele retirou vivamente a mão, exclamando involuntariamente: - "Ai! feri-me!..." Era que a travessa lhe havia apertando os dedos contra os espinhos da rosa" (11).

Neste caso, como no ouiro, estamos diante do jogo constante, feito de avanços e recuos, de apelos e fugas alternadas -, que explode na festa. Aqui, no en:anto, o negaceio não visa a satisfação direta das necessidades sexuas, não é o momento preparatório de uma posse próxima e efetiva. Pois a corte amorosa complica-se, prolonga-se indefinidamente, colfundindo os elementos sensuais com a atração espiritual, favorecendo contactos mais íntimos e uma vagarosa acomodação entre os sexos (12). Pelo testemunho dos documentos literários, vemos zomo é possivel, na contradança, burlando a vigilância, cerrar mis vivamente os dedos do par (13), ou libertando as mãos da luva sentir melhor o frêmito do corpo enlaçado (14). Uma pequena regra que se esquece, quando se toma inadvertidamente a mão de dama em vez de apresentar-lhe a sua

(11) J. M. Macedo - A Moreninha, pg. 160.

(12) J. M. de Macedo - Moreninha, pg. 190:

"Ter a ventura d/receber o braço de uma moça bonita e a quem se ama, apreciar o doci contacto de uma bem torneada mão, que tantas noites se tem sonhad beijar; roçar às vezes com o cotovelo um lugar sagrado, voluptuoso palpitantes; stntir sob sua face o perfurmado bafo que se esvaiu dentreos lábios virginais e nacarados, cujo sorriso se considera um favor docéu; apanhar o leque que escapa da mão que estremeceu, tudo isso.. mas para que divagações?"

(13) José de Alencar, Iiva, in Perfis de Mulher, Livraria Martins Editora, São Pau'o, 1944, g. 24:

"Emília não vlsava; nunca nos bailes ela consentiu que o braço de um homem the cigisse o talhe. Na contradança as pontas dos seus dedos afilados, semre calçados nas luvas, apenas roçavam a palma do cavalheiro; o meno e:a quando aceitava o braço de alguem. Bem diferente nisso de ertas moças que passeiam nas salas reclinadas ao peito de seus pares."

(14) José de Alenca, Diva, pg. 25:

"Tirando-apara dançar uma noite, ela ergueu-se e ia dar-lhe o braço; mas retraiuse logo e tornou a sentar-se.

- Descule-me Não posso dançar.

- Por qe moivo, D. Emília?

Ela calouse, ma fitou-lhe as mãos com olhos tão expressivos que o moço comjreendeue corou: çá-las."

- Tem razão. Tirei as luvas para tomar chá e esqueci-me de cal- 
(15); um abandono que se imprime ao corpo reclinando-o sobre o peito do cavalheiro ao aceitar-lhe o braço para o passeio na sala tudo acelera o coração e antecipa o desejo que, na vertigem da valsa, irrompe francamente (16).

Para sentir como tais situações são excepcionais, basta procurarmos o seu eco nos romances da época e no comentário dos mais velhos:

"- Sim, arrepio-me ao ver que um pobre pai, lá no tal baile suntuoso, sente que se aproxima de sua filha querida um marmanjo, que ela nunca viu, que não sabe se é um moço de bem ou um mancebo desmoralizado, e que no entretanto leva pelo braço a inocente menina, passeia e conversa com ela horas inteiras, diz-lhe coisas que a fazem rir, que a fazem corar, que a fazem estremecer" (17).

Mas é preciso que seja assim. Pois a festa pode ser a lenta ante-câmara do casamento, onde os seres se auscultam e os instintos se jogam - como diria Huizinga — produzindo não só os contactos fortuitos, as conversas a dois, as confissões veladas cheias de reticência, mas as competições de salão. É o caso das charadas, descritas por Thackeray e muito em voga na primeira metade do século, tando na França como na Inglaterra (18), dos quadros vivos de

(15) José de Alencar - Diva, pg. 24-5:

"Uma noite, dansando com o Amorim, sócio de seu pai, recolheu a mão de repente, e deixou cair sobre êle um dos seus olhares de Juno irritada:

- Ainda não sabe como se dá a mão a uma senhora? đisse com desprezo (...) o Amorim em uma das marcas, tinha-lhe inadvertidamente tomado a mão, em vez de apresentar-lhe a sua."

(16) Admirável exemplo do enlevo sensual em que a valsa arremessa os pares é toda a passagem do baile, no final de Senhora, em que Aurélia e Fernando deixam-se levar no turbilhão, verdadeiro substitutivo de uma posse frustrada (Alencar, Perfis de Mulher, pgs. 436, 7, 8 e 9).

(17) Macedo - Rosa, pg. 13.

(18) Em Vanity Fair (pgs. 574 e sgs.),Thackeray descreve com minúcia este jogo de salão em que Mrs Crawley sobressai com grande sucesso, numa das brilhantes recepções de Gaunt-House.

Na crônica de 20-2-1859, da Revista Popular, encontramos, aliás, menção de um passatempo, talvez semelhante a esse e já em voga no Brasil:

"No oitavário do consórcio dos S.V., reunriam-se em sua chácara, no Andaraí, os seus afeiçoados. ouve um lindo sarau que começou pela representação de um espirituoso provérbio e terminou com algumas voltas de polcas e mesuras dos lanceiros (...) Apresenta-se agora uma novidade, para nós, bem entendido, e essa novidade, como todas, vai encontrando seus inimigos, quero falar-vos das representações de comédias em sala (...) É uma moda que nos veio da Inglaterra, disse ontem em certa roda um indivíduo, a quem acabavam de ler uma das cartas." 
que nos fala von Boehn (19), espetáculos "que supunham quer de quem tomava parte, quer de quem representava, extensos conhecimentos literários e artísticos"; dos nossos jogos mais provincianos das prendas, das flores, das sentenças, que Macedo assinala como passa-tempos nas chácaras do Rio de Janeiro (20). Todos eles substituíam muitas vezes as dansas, "dando às senhoras que possuíam beleza, oportunidade de exibir seus encantos, e ao número mais restrito das que possuíam espírito, de revelar sua argúcia" (21).

Contudo, entre todos os elementos que entram em jogo no exibicionismo desenfreado da festa, a moda é um dos mais eficientes. Uma conexão íntima sempre a ligou às reuniões sociais, pois juntamente com a força física, as armas, a inteligência e os ardis, é a vestimenta uma instrumento de luta, quer ela se trave entre os grupos ou entre os sexos. Já entre os povos primitivos observamos uma preocupação especial com o ornamento, a tatuagem, o penteado, o saiote cerimonial, naqueles momentos em que, ao se reunirem todos os membros do clã ou da frátria, cada qual deseja, na competição que imediatamente se estabelece, oferecer aos outros a melhor imagem de si. A metamorfose das relações é acompanhada pela metamorfose do ser.

A roupa simples da vida comum, ajeitada às exigências triviais da realidade, substitui-se na festa a forma fantasmal que o narcisismo apõe ao corpo e ao rosto. O universo do sonho é também o reino das transmutações. E uma nova personalidade emerge no momento de exceção, quando à esfera da pessoa se acrescenta uma ambiência fictícia, feita de novas cores com que se enriquece o matiz natural da epiderme (22), de novas curvas que se adicionam

(19) La Moda, vol. II, pg. 136:

"Os quadros vivos que, como vimos, apareceram pela primeira vez por ocasião do Congresso de Viena, ainda eram realizados de maneira grandiosa, e foram, naquele ano, o motivo de não poucas festas. Assim, na corte de Berlim, se representou em 1818 a festa do amor celeste, em 1821 o poema de Moore Lalla Rokh, em 1843 uma festa na corte de Ferrara - todos esses espetáculos que supunham, quer de quem tomava parte, como de quem representava, extensos conhecimentos históricos, literários e artísticos."

(20) Em Rosa, pg. 54, Macedo descreve esses jogos.

(21) Thackeray, Vanity Fair, pg. 575.

(22) Ao contrário do que se costuma pensar, no século XIX as mulheres pintam-se bastante, como ressalta dos anúncios de jornais da época, dos artigos de jornais e dos romances. Principalmente na primeira década e nos últimos vinte ou trinta anos, pois o romantismo difundindo o gosto pela palidez e pelas heroínas evanescentes, banira as cores artificiais. Cunnington (Feminine Attitudes, pg. 45) refere-se aos anúncios das revistas femininas da primeira década do século, que oferecem sicilian 
ao corpo, ajustando muito os vestidos ou multiplicando as formas com o recurso dos folhos, dos babados, dos ruches e franzidos. "O perfume cumpre a mesma missão por meio do olfato, que o adorno por meio da vista" (23). E esta irradiação do corpo feminino, atinge os vários sentidos do homem, aprisionando-o em sua atmosfera. $\mathrm{E}$ que as barreiras, derivadas de uma moral estreita, impedindo a admiração estética do corpu nu, deslocavam em grande parte o interesse para o envólucro do corpo, e a avaliação dos valores eróticos baseava-se tanto nas modas de vestimenta, como na apreciação da beleza física.

O vestido decotado satisfazia, a um tempo, essa dubiedade no julgamento, criando um equilíbrio harmonioso entre o trajo e a nudez, fazendo nascer do contraste entre o esplendor de um e a beleza de outro, a emoção estética perfeita. A discreta vestimenta diurna cedia lugar ao exibicionismo da indumentária noturna (24), quando com os recalques, transbordavam das vestes as formas escondidas. O vestido da mocinha era, é verdade, paradoxalmente mais

bloom of youth, liquid vegetable rouge, pomade for colouring lips, etc., os quais iriam desaparecer das publicações vitorianas. Por voltas de 1860 , contudo, o gosto pela pintura retorna, trazido pelas heroínas do demi-monde, e a Saturday Review publica uma série de artigos condenando veementemente tão abominável costume, culminando com um que se intitula The girl of the period: "A mulher do momento é uma criatura que tinge os cabelos e pinta o rosto, os dois elementos principais de sua religião pessoal; cuja idéia fixa na vida é divertir-se e luxar o mais que pode, e cujo vestido absorve toda a capacidade de pensamento e de inteligência de que é capaz." (Citado por Cunnington, op. cit., pg. 208).

Em 1873 The Queen comenta entre outras coisas: "Elas esperam que os maridos lhes tolerem todos os hábitos: sua custosa e incessante mudança de modas, seus pós e cosméticos, suas construções monstruosas de cabelos tintos e falsos, seus corpos estofados - todas as curvas feitas pela costureira e não pela natureza." (Citado por Cunnington, op. cit., pg. 208).

Tais hábitos não eram desconhecidos de nossas recatadas donzelas e o próprio Macedo os menciona, de passagem, na Moreninha (pg. 164).

"Augusto, uma idéia felizr Vais vestir-te no gabinete das moças (...) Orá! pois tu deixas passar uma tão bela ocasião de te mirares no espelho em que elas se miram?... de te aproveitares das mil comodidade e das mil superfluidades que fo migam no toucador de uma moça? ... Vai ... Sou eu que t'o digo: ali acharás banhas e pomadas naturais de todos os países, óleos aromáticos, essências de formosura e de qualidades, águas cheirosas, pós vermelhos para as faces e para os lábios, baeta fina para esfregar o rosto e enrubescer as pálidas; escovas e escovinhas, flores murchas e outras viçosas..."

(23) Simmel - Sociologia, pg. 249.

(24) Em capítulo anterior - "A cultura feminina" - nos referimos a essa mudança brusca nos princípios da vestimenta, que separava o dia da noite, ou melhor a existencia quotidiana da vida de exceção. 
modesto que o da senhora casada. Ainda sem marido, ninguém mais do que ela devia tirar proveito dessa exibição franca onde cada uma ostentava as suas prendas, acenando aos homens com os sequestrados encantos. A licença da festa, porém, não ia até esse extremo, e se permitia o negaceio, a faceirice, os olhos quebrados atrás do leque, conservava à sua volta um certo recato que, acentuando o mistério, não era mesmo eficiente na atração amorosa. Para a mulher casada a margem de concessão era maior. O matrimônio, arrancando-a ao estado de inconsciência e total ignorância dos fatos da vida, ao mesmo tempo que abrandara os tabus dera-lhe uma relativa desenvoltura, um domínio de si e de seus instrumentos de êxito. Exibia-se porisso; e talvez porque uma experiência efetiva, frequentemente decepcionante, impelia-a a buscar novas formas de plenitude, no olhar admirativo do próximo, no roçar das casacas por seus braços nus. A mocinha expandia-se, de alguma forma, entregando-se à poliandria dos devaneios e povoando a solidão com heróis de folhetins: ela, menos ingênua, necessitava substitutivos mais eloquentes. E na festa, à distância, era como se estivesse se oferecendo aos homens através do decote. Esta relação simbólica, num tempo em que o casamento se determinava por razões sociais, econômicas ou domésticas e não por acentuada preferência pessoal, era que impedia, muitas vezes, a queda no adultério. Passada a breve vertigem dos sentidos, em que dançava à beira do abismo, podia a matrona voltar, aplacada, a cuidar dos filhos e das meias do marido.

Para o grupo masculino a moda tem uma importância diversa na competição a que a festa dá lugar. Não só porque a valorização do homem repousa, como vimos noutro capítulo (25), em elementos diferentes de prestígio, — a força da personalidade monopolizando o impulso exibicionista que outrora se expressava na vestimenta como porque sendo ele quem escolhe, os motivos sexuais vêem-se relegados para segundo plano. Os trajos vistosos, guarda-os, agora, para a intimidade do lar: os roupões opulentos de damasco ou veludo, às vezes ornados de galões de ouro (26). Em público, porém, nada o deve distinguir a não ser o corte impecável e a simplicidade britânica do Jockey Club. Nas reuniões mundanas ao lado do esplendor das mulheres, os elegantes se assemelham, na expressão feliz do naturalista Edmond Perrier, "à autant de larves se glissant parmi les fleurs" (27).

(25) Ver capítulo II, "O Antagonismo".

(26) Ver Max von Boehn, La Moda, vol. III, pg. 106.

(27) Citado por Braunschvig: La femme et la beauté,pg. 112.

Aliás, isso era verdade mesmo tratando-se do dandy ou do lion, para quem a vestimenta, no entanto, desempenhava um papel muito impor- 
Apagando-se diante da companheira o homem já está, aliás, manejando a sua mais poderosa arma, o galanteio, pois a modesta penumbra na qual se insinua, desistindo do ornato e erigindo o preto em sua cor, é um mudo cumprimento à mulher, só ela detentora da beleza. Daí em diante o seu prestígio nos salões dependerá tanto da elegância e do talento, como dessa habilidade de dirigir um elogio, de, sem ofender o pudor, alimentar a vaidade feminina através das delicadas investidas da corte amorosa (28). Sob o olhar cúmplice da sociedade, quando a mulher se abandona simbolicamente ao companheiro, por meio dos recursos da vestimenta, é pelo galanteio que, por sua vez, ele, simbolicamente, a propicia e domina. Galanteio que evolui do aplauso às virtudes femininas à louvação do rosto e do corpo (29). Contudo, na trégua indecisa da festa, antecipando a posse efetiva que pode se estar preparando é no elogio das roupagens que o impulso amoroso se desafoga. Talvez agora compreendamos melhor o interesse excessivo que a moda despertava nos escritores da época, o afã com que descrevem as cores, os tecidos, as jóias, os perfumes, enfim, toda a ambiência mundana da mulher. A posse das roupagens, o acariciar com os olhos e as palavras, a máscara da ves-

tante, funcionando, frequentemente como instrumento de ascensão social. Contudo, como o ideal de elegância masculina não é mais a beleza mas a correção (ver Goblot, La barrière et le niveau, pg. 75 e sgs.) é através da simplicidade que se celebrizam o Brummel, Alfred D'Orsay e mesmo os heróis mundanos de Balzac e Proust: Rastignac, Rumbempré, Swann, Saint Loup, etc. . O dandy corresponde a um novo conceito de elegancia bastante diverso do incroyable ou do macarroni.

(28) Examinando a vida social do Brasil desta segunda metade do século, notamos que uma curiosa conexão se estabelece entre a estação mundana e a abertura das Câmaras. "Salve pois a formosa quadra dos folguedos" - diz o cronista social da Revista Popular (10 de maio de 1861) - "o clube já anuncia nova existência e prepara honrosa recepção aos filhos da cabala". Parece que sem os deputados o Rio de Janeiro não vivia e as donzelas não achavam graça nos saraus: "Quando desabrocham as flores e zumbem os zangões, é sinal certíssimo de estarmos na primavera. Da mesma sorte quando a cidade povoa-se de moças e os deputados vêm chilrando aninhar-se na cotte, podemos afirmar que chegamos à quadra festiva." (Revista Popular, Crônica social de 10 de junho de 1860). Donzelas e deputados, eis portanto as duas condições indispensáveis à vida social da corte. - Donde viria o sucesso mundano dos últimos? Talvez do acordo admirável entre a elegância, o brilho público da carreira e a habilidade maneirosa, treinada na profissão que, transplantada para os salões cariocas, refloria no talento inexcedivel dos galanteios.

(29) Tarde - L'opinion et la foule, Felix Alcan, 1904, pg. 145:

"Pode-se notar, no entanto, que os cumprimentos endereçados às mulheres, evoluíram de manei:a inversa aos precedentes. Louvou-se, inicialmente, as virtudes das mulheres, seu espírito de ordem e de economia, seu talento como tecelã, depois como musicista, antes de elogiar-se se, publicamente pelo menos, sua beleza física", etc. 
timenta cingida muito rente ao corpo, representava, naquela época de severa vigilância, a única intimidade permitida. Nela se expandiam os recalques, enquanto o tempo não abrandava os tabus, destruindo também o belo simbolismo do amor.

Faceirice e galanteio - eis portanto as duas faces de uma posse simbólica que se realizava na festa, atenuando um pouco as tensões entre os sexos. Evasão, é certo, mais necessária para a mulher, bloqueada antes e depois do casamento por uma moral puritana, que para o homem, principalmente o elegante, o qual, antes e depois do casamento, circulava com desenvoltura entre dois mundos, o monde e o demi-monde.

Mas se uma das funções da festa é modificar as relações entre os sexos, a outra igualmente importante é modificar as relações entre as classes. Nas sociedades primitivas as cerimônias periódicas têm por objetivo principal apertar os laços de solidariedade que se haviam afrouxado durante uma parte do ano quando os grupos, clãs ou frátrias, pela necessidade de subsistência ou organização social, espalham-se pelo espaço geográfico, vivendo em estado de individuação e isolamento nos pequenos grupos familiares (30). Nas sociedades urbanas do século XIX, os indivíduos se cotovelam na aproximação física das cidades; contudo, a hierarquização limita cada indivíduo à existência em sua classe, fazendo-o perder o contacto com o resto da comunidade. E se a festa adquire importância é por anular de certa forma os afastamentos no espaço social.

No século XVIII, por exemplo, quando as tensŏes existentes entre os vários grupos eram profundas e a distância social estabelecia-se de maneira muito nítida entre a nobreza e a burguesia, os bailes públicos rompiam, periodicamente, a estrutura rígida da sociedade; e as classes, separadas na vida diária por barreiras intransponíveis, dançavam juntas, se confraternizando. $\mathrm{E}$ isso era frequente não só na Inglaterra, em Ranelagh, em Vauxhall Gardens, quando o extraordinário desenvolvimento da indústria já prestigiava a burguesia, mas principalmente nas cortes muito estritas como as de Viena e dos Duques de Würtemberg (31). A breve trégua, realizando uma daquelas foules d'amour de que fala Tarde, (32) descarregava a atmosfera; os diferentes grupos quebravam o isolamento em que se segre-

(30) Para a festa, como criadora de solidariedade ver:

Mauss - "Essai sur les variations saisonnières des sociétés eskimos (essai de morphologie sociale)", in L'Année Sociologique, Tomo IX, 1904-1905.

Durkheim - "Les fo"mes élémentaires de la vie religieuse", 3a. ed., Felix Alcan, Paris, 1937. 
gavam, para reforçar, graças à troca de experiência e o conhecimento mútuo, a coesão geral da sociedade.

A preponderância da democracia política, no século XIX, está longe de modificar este estado de coisas. A reestruturação de camadas e o deslocamento da dominação político-econômica para a burguesia, não suprimiu, apenas criou novos afastamentos de fortuna. profissão, família, posição social. E, como os séculos anteriores, o XIX se viu obrigado a proporcionar, de tempos em tempos, oportunidades excepcionais de contacto entre os indivíduos - principalmente entre aqueles que, situados nos limites da barreira, estavam sempre em vias de aproximar-se ou de afastar-se.

Exemplo disto, entre outros é a verdadeira mania ambulatória que irrompe então por toda a parte e que o desenvolvimento das estradas de ferro acelera. Se na época de Luis Felipe já eram frequentes os banhos dos Pirineus, Luchon, Pau, Arcachon (33), de 1850 em diante o hábito das estações balneárias se generaliza e a sociedade se transfere, num ritmo constante, para Spa, Baden Baden, Monte Carlo etc. Ora, o deslocamento no espaço recoloca o problema da classe social (34), e naquelas cidades de veraneio em que os duques, os marqueses, os grandes capitalistas, desfilam ao lado dos aventureiros de todo o mundo, perdia-se o contacto com a realidade e as linhas de demarcação esboroavam. Uma euforia como que se apossava desse conglomerado heterogêneo que, como os bailes de máscaras das cortes cerimoniosas, misturava inesperadamente a burguesia sólida aos arrivistas, as cocottes em voga às donzelas casadouras, a nobreza rural à nobreza cosmopolita das grandes cidades. Neste universo à parte, separado do grande universo insosso da vida quotidiana, o sonho se concretiza, a mocinha casa com o bailarino (35) e a poderosa princesa de Luxemburgo se detém um momento junto ao veranista modesto, para apartar-lhe cordialmente a mão (36). Na sociedade "estática" os contactos se ampliavam na festa beneficiente - nas loterias para os pobres, nos bazares de caridade - quando, sentindo a sua insuficiência, as elites se viam obrigadas a apelar para as outras camadas.

(31) Ver Max von Boehn:Modes and Manners, vol. IV, Harrap, Londres, 1935, pg. 292. Aliás, uma das diversões favoritas dessas cortes, sempre às voltas com as questōes de precedência, eram os Wirtschaften, "divertimento no qual toda a sociedade vestia-se como camponeses, abandonando a etiqueta por algum tempo" (pg. 289).

(32) Tarde - L'opinion et la foule, pg. 45.

(33) Ver Max von Boehn, La Moda, vol. II, pg. 145.

(34) Este problema foi tratado no capítulo IV, "A luta das classes".

(35) Ver Proust - A l'ombre des jeunes filles en fleur III, pg. 157.

(36) Ver Proust - À l'ombre des jeunes filles en fleur II, pg. 138 e sgs. 
Porém, era nos salóes particulares que os laços se estreitavam mais intensamente e as aproximações se faziam de maneira efetiva. Aqui, mais do que nos dois casos anteriores, a festa construía, por um momento efêmero, toda uma estrutura social em que reinava uma unidade - aproximadora de diferentes grupos e camadas - inexistente na vida comum. Naquele pequeno lapso de tempo e naquele limitado espaço, forjavam-se de novo as relações que unem os indivíduos e os situam uns em face dos outros. De tal forma que, mais importante que a estrutura real de todos aqueles grupos que se defrontavam era a estrutura momentânea, fugidia e efêmera a que a festa dava origem. Pois o respeito que a vida de salão ainda exprime de certo modo por uma hierarquia já se encontra bastante atenuado, porque o privilégio do convite estabeleceu a igualdade entre as pessoas, abrindo-lhes como que um crédito de confiança. Contudo, para que esta igualdade se solidifique cada um deverá entrar no diapasão geral, confundir-se do modo mais perfeito aos grupos dominantes, copiando-lhes o comportamento, a maneiras, a vestimenta. Por este lado a festa funciona como a grande fantasia, o mito de Borralheira. Agora, os espezinhados, aqueles que, por quaisquer motivos, foram postos à margem, penetram no mundo recluso e aí vivem como iguais. O seu sucesso dependerá, em grande parte, da capacidade de evoluir com desenvoltura num meio estranho, fazendo com que se esqueça a procedência - tarefa tanto mais difícil quanto, encerrado dentro de um espaço restrito e consciente de estar vivendo um momento de exceção, cada detalhe do comportamento ou da aparência é medido e pesado pela maioria. Mas se a gaffe que se dá - o cumprimento efusivo a quem bastava apenas um aceno de cabeça, a insistência em voltar sempre ao obscuro assuntinho de grupo, negligenciando as vestido - desnivelam o indivíduo dentro dessa estrutura fictícia, um vestido desnivelam o indivíduo dentro dessa estrutura fictícia, um acidente amável como a solicitude de um grande personagem ou o sucesso de uma bela toilette elevam-no imediatamente aos olhos de todos (38). E que nesse momento em que se perdem os contactos com a realidade e é difícil lembrar a posição efetiva do indivíduo, o essencial é o que se desenrola sob as vistas do público limitado. Daí a enorme importância que a moda adquire, pois exprime adequação

(37) Ver Tarde, op. cit., pg. 122 em nota.

(38) Ver Thackeray, Vanity Fair, pg. 568-569.

"(...) este grande e famoso líder da moda reconheceu Mrs Rawdon Crawley, fez-lhe a corte a mais rasgada (...) convidou-a para a sua casa e falou com ela duas vezes, da maneira mais pública e condescendente durante o jantar. O fato importantíssimo espalhou-se por Londres inteira naquela mesma noite. As pessoas que andavam querendo apupar Mrs. Crawley, silenciaram. (...) Em resumo, ela foi admitida na alta sociedade." 
ou a desarmonia do indivíduo com uma sociedade que lhe abre os braços.

O universo da festa não tem passado. "Admitir uma pessoa em vossa casa é supô-la digna de habitar a vossa esfera", diz Balzac (39). E como o salão, oferecendo a todos iguais oportunidades de brilho, destrói as distâncias, cada um esforçar-se-á por restabelecê-las através dos sinais exteriores da vestimenta. Poucos são os enquadrados dentro de um ritmo social em que a festa é uma das constantes. Para a maioria, como dissemos, ela representa a ruptura na existência morna dos trabalhos e das atribulações, a porta que se abre sobre o mundo do sonho. Afastados do convívio da sociedade elegante, dezenas de grupos marginais que para ela tendem ou que dela procedem, desnivelados por insucessos quaisquer, são de quando em vez chamados para a comunhão dos salões - pois que, de quando em vez, como que para renovar os seus quadros, as elites os põem à prova, testando a sua capacidade de adaptação ou a presença lúcida de uma memória que ainda não esqueceu os antigos gestos e os velhos requintes. Nobres empobrecidos, burgueses em ascensão, arrivistas ambiciosos, todos se preparam para a grande mascarada, atentos às minúcias da vestimenta, à rúbrica do grande costureiro e às normas dos livros de maneiras. Os menos bafejados pela fortuna substituem o luxo das roupagens pela argúcia, fazendo o trajo concordar consigo, compondo um sutilíssimo esquema cromático entre a cor e a consistência do tecido, o colorido dos olhos, a indefinível tessitura da pele. Ou, servindo-se do privilégio de uma prima rica, valorizam com as jóias emprestadas o vestido feito em casa. Não importa o que se passou além dos limites da festa: o esforço titânico para penetrar no mundo dos eleitos, as baixezas a que o indivíduo se curvou, os insultos que sofreu, a corrida desesperada atrás da moda, na qual não se pouparam nem sacrifícios, nem humilhações (40). Quando Rebeca, segundo a descrição de Thackeray, surgir no baile de Bareacres e todas as lunetas se assentarem sobre a sua maravilhosa toilette, enquanto à sua volta os dandies se atropelam, ninguém ha-

(39) Traité de la vie élégante, pg. 69.

(40) Vanity Fair, pg. 548:

"Havia famílias em Lonđ̈es que sacrificariam, de bom grado, a renda de um ano para receber tal honra das mãos daquelas grandes damas. Mrs. Frederick Bullock, po: exemplo, teria ido de joelhos de Mayfair a Lombard Street se Lady Steyne e Lady Gaunt a estivessem esperando na cidade para erguê-la e dizer: "Apareça em nossa casa sexta-feira próxima" - não a uma das grandes reuniões e grandes bailes de Gaunt House, onde todo o mundo ia, mas às sagradas, inap:oximáveis, misteriosas, deliciosas reuniões a que era um privilégio ser admitida, uma honra e, na verdade, uma bênção."

Proust - Sodome et Gomorrhe II, vol. I, pg. 45: 
verá que se lembre da pobre governante saída um belo dia das mãos de Miss Pikerton. Entre si, as senhoras sussurram que foi raptada por Crawley de um convento e é uma longínqua parente dos Montmorency (41).

Ela mesma, ao cobrir-se de plumas e embrulhar-se nas rendas do vestido, verá como por encanto apagar-se o passado, banido o fantasma das dívidas que aumentam e não há possibilidade de saldar. Com a vestimenta, um novo ser acomoda-se em seu corpo, lento de gestos, majestoso, naturalmente afeito à alta posição que, por fim, atingiu (42). O que vale é a breve existência de rainha.

Porém, uma tal esperteza tem seu prêmio. E no dia seguinte, quando os jornais proclamarem ao público sequioso, prisioneiro dos lares, "as plumas, os véus, os soberbos diamantes" (43) de Becky, o sonho já estará forçando a realidade e a estrutura efêmera da festa se concretizando na vida. Um pouco mais de audácia, algumas amarras com o antigo ambiente que será preciso cortar sem piedade, e a arrivista das esferas populares ou pequeno-burguesas terá, com os seus encantos e desgarres, completado o salto gracioso que recebeu da festa o grande impulso (44).

A festa possibilita, portanto, no século XIX, uma reorganização das elites, pela introdução de novos membros capazes. A grande cidade modificou a relações sociais e atenuou as barreiras através das mudanças bruscas de fortuna. Agora a riqueza é provisória e passa de mão em mão com os objetos que se possue. A vitalidade do sistema de classes enfraqueceu e as ligações que o indivíduo mantém com o seu grupo são frouxas, podendo tanto apertar-se como desprender-se de uma vez. A festa adquire, nestas circunstâncias, o carater de um cerimonial de iniciação, onde entram em jogo mais as qualidades pessoais de cada um que os atributos de sua classe. Poris-

"Mas as mulheres do tipo da embaixatriz otomana, ainda recentes na sociedade, não deixam de brilhar, por assim dizer, por toda a parte ao mesmo tempo. Elas são úteis a êsse tipo de reuniões que se chamam um sarau, um raout e que, para não perdê-lo, ter-se-iam feito conduzir moribundas."

(41) Vanity Fair, pg. 316.

(42) Vanity Fair, pg. 536.

"Ela entrou no veículo como se fosse uma princesa acostumada toda a vida a ir à Corte, sorrindo com graça ao lacaio e a sir Pitt, que seguiu-a na carruagem".

(43) Idem, pg. 541.

(44) Cfr., além do estudo de Thackeray, os que Proust consagra à carreira da cocotte Odette de Crécy, em " $A$ la recherche du temps perdu" e Machado de Assis à Sofia Palha, em "Quincas Borba" - todos eles de lúcida penetração sociológica. 
so o jovem provinciano, pobre mas talentoso, recebido por complacência nas altas regiões da sociedade, deve exceder-se no convívio dos salões (45), demonstrando pelos detalhes cuidados de sua toilette, pela desenvoltura contida dos gestos, pelo modo de pegar na chícara ou oferecer o braço à dama, de velar o tom da voz, não se exibindo nas conversas, a sua capacidade perfeita de adaptação. $O$ vagaroso polimento das arestas, efetua-se dia a dia nas reuniões sociais e oscila entre a derrota de hoje e o sucesso de amanhã, quando o amargo aprendizado, feito de tacteios, de desânimos, de novas investidas desesperadas, acompanha a cadeia longa de provas que the vão sendo antepostas e cuja vitória final há de conferir ao neófito a cidadania na classes mais alta. Exemplo admirável dessa iniciação é a trajetória de Lucien de Rubempré, que evolui de obscuro e mal vestido poeta de província a dandy parisiense. Observando a reação que suas roupas causam nos membros da elite e a postura inconfundível dos elegantes, vai, à medida que se faz o aprendizado, substituindo gradativamente os seus trajos. A redingote de Angouleme é, já no primeiro dia de Paris, abandonada por son fameux habit bleu (46), o qual, parecendo-lhe odioso em confronto com a vestimenta dos gentis-homens que vê desfilando pelas ruas, é posto de lado em favor de uma indumentária completa do Palais Royal. Mas esse trajo verde, com que se apresenta na Opera, dá-lhe o ar de "um hømem que se havia vestido pela primeira vez na vida" (47) e a chacota de que é vitima, leva-o a procurar, desesperado, o Staub, o alfaiate mais célebre dessa época (48). Pela primeira vez Rubempré sente-se bem posto e gracioso e as mulheres o fitam, atingidas pela sua beleza (49). Como Rastignac, iniciou a investida contra a série interminável de provas que Paris opõe ao provinciano e que solicitam uma perseverança, extraordinária e uma desmedida ambição.

Portanto, se de um lado as classes mais altas opõem-se à brusca penetração em seus quadros de quaisquer elementos oriundos de outras camadas, de outro, possibilitam aos mais aptos, àqueles que vencem galhardamente todos os obstáculos, o ingresso no mundo dos eleitos. E o que observamos ainda em "Pigmalião" de Bernard

(45) O mesmo poderíamos dizer do bacharel mulato, no Brasil, cuja ascensão fez-se frequentemente, através dessa desenvoltura mundana - "bacharéis mulatos - retóricos e afetados no trajo uns, outros tão à vontade na sobrecasaca e nas idéias francesas e inglesas, como se tivessem nascido dentro delas". (Gilberto Freyre, Sobrados e Mucambos, pg. 324).

(46) Balzac - Illusions perdues, "Deuxième Partie: Un g:and homme de province à Paris", pg. 203.

(47) Idem, idem, pg. 221.

(48) Idem, idem, pg. 227.

(49) Idem, idem, pg. 234. 
Shaw, onde o treinamento intensivo de Liza, a florista arrancada à sarjeta, e que se coroa com o sucesso final da recepção na Embaixada, é outro belo exemplo dessa iniciação mundana de que falamos, e que não depende da categoria social do indivíduo, mas de uma certa maneira de falar, de comportar-se, de vestir-se, que é possível adquirir .

Mas se de tempos em tempos a sociedade abre algumas comportas pelas quais não só as tensões entre os sexos se aliviam como também, excepcionalmente, as ascensões se efetuam (Borralheira retornando ao palácio como esposa do príncipe simboliza os dois aspectos) as mais das vezes, passada a vertigem, passando o tempo de "metamorfose do ser", estabelecem-se com a antiga ordem os antigos recalques. Pois podem não ser amáveis as recordações que se traz para casa, quando da reunião arbitrária de eleemntos de vários grupos, surge em cada um, mais nítida, a noção de sua verdadeira posição social. Em Paris, perdido no meio da sociedade elegante, Lucien de Rubempré sente, mais do que na província, o seu ar de filho de boticário ( 50$)$; no camarote da Ópera a vizinhança brilhante de Mme d'Espard acentua a imperfeição das maneiras e o vestido fora de moda da provinciana Mme de Bargeton (51).

A exposição feita acima ressaltou a natureza da festa como fato social, acentuando a sua correlação com a moda e as atitudes mundanas. Vimos que ela funciona como fator de reforço da estrutura social - no caso, pelo contacto momentâneo entre grupos e camadas - e como meio de recrutar elementos capazes de enriquecer e mesmo recompor as elites. Mas, porisso mesmo, ela desempenha outra função, complementar e de certo modo antagônica. Com efeito, a união efetuada pela festa tem por consequência anular provisoriamente as barreiras para, em seguida, - e depois de admitidas as pessoas capazes de se ajustar ao estilo de vida das camadas mais altas - erguê-las novamente com vigor, manifestando a separação entre as classes e entre as camadas ou círculos de uma classe. Assim, ao reunir indivíduos de estratos diversos, possibilitando-lhes idêntica oportunidade de brilho, as camadas mais favorecidas estão lançando mão de um subterfúgio malicioso para sublinhar os afastamentos que, de antemão, comprometeram. Estão realizando, efetivamente, aquela experiência de sociologie amusante que Proust declara ter sempre desejado fazer, colocando Mme. Cottard ao lado de Mme. Vendôme... "Só as almas esquecidas e os pobres sabem observar, pois que tudo as magoa e a observação deriva de um sofrimento", diz Balzac (52).

(50) Balzac, op. cit., pg. 206.

(51) Balzac, op cit., pg. 211

(52) Carta de Balzac a Mme Hanska, em começos de 1833 - in Brunetière, Honoré de Balzac, Nelson, Paris, s/d, pg. 166. 
A consciência aguda, desenvolvida nos confrontos de vida social, leva os mesmos favorecidos a distinguir na atmosfera que os envolve qualquer coisa de inacabado, um vago ar de mentira revelando-se nas jóias emprestadas, nos folhos opulentos que, caindo pela saia escondem o descuido da lingerie; no vestido feito em casa onde sobressai o bordado em que se gastaram os olhos. Tudo isso, que proclama a corrente ininterrupta de pequenos sacrifícios, a obscura vida a que o indivíduo se curvou para espandir-se glorioso no breve momento de exceção, também revela aos seus olhos a desarmonia profunda, a profunda falta de unidade na existência. Dentro de nós mesmos, indiferente ao sucesso transitório, permanece inexoravelmente desperta a idéia de nosso ser quotidiano ao qual opusemos a máscara da festa. E a lembrança constante do artifício que nos embaraça e nos perturba, e o nosso enleamento, contrastando com a desenvoltura dos outros, patenteia, aos olhos de todos, aqueles afastamentos que não se conseguiu disfarçar sob o cuidado da vestimenta. Assim, a pausa passageira que se abriu em cada vida pode tanto arrebatar o indivíduo na vertigem de um instante, como atirá-lo na consciência mais aguda do borralho.

Depois da mascarada, brilhando mais lúcida a verdade interior de cada um, a ordem da sociedade estará salva .

GILDA ROCHA DE MELLO E SOUZA 